https://doi.org/10.34142/23129387.2019.60.10

UDC: $159.923 .32 ; 316.612$

ORCID 0000-0003-2511-6803

ORCID 0000-0002-9169-5471

ORCID 0000-0002-7409-3532

ORCID 0000-0003-1939-1980

\title{
COGNITIVE PREDICTORS OF SCHOOLCHILDREN'S HUBRISTIC MOTIVATION
}

\author{
Karyna I. Fomenko ${ }^{1 A B C D}$, Olena O. Shcherbakova ${ }^{2 A B E}$ \\ Nadiya Zhukova ${ }^{3 B E}$, Viktoriya Nadyon ${ }^{4 B E}$ \\ ${ }^{1}$ H.S. Skovoroda Kharkiv National Pedagogical University, Ukraine \\ Doctor of psychological sciences, \\ Associate Professor of Practical Psychology Department \\ E-mail: karinafomenko1985@gmail.com \\ ${ }^{2}$ State Institution "Institute for Children and Adolescents \\ Health Care of the National Academy \\ of Medical Sciences of Ukraine", Kharkov \\ E-mail: lenascherbakova@ukr.net
}

${ }^{3}$ H.S. Skovoroda Kharkiv National Pedagogical University, Ukraine graduate student of Practical Psychology Department

E-mail: etoile.lamberti@gmail.com

${ }^{4}$ H.S. Skovoroda Kharkiv National Pedagogical University, Ukraine graduate student of Practical Psychology Department

E-mail:vik_tory183@ukr.net

Authors' Contribution:

A - Study design; B - Data collection; C - Statistical analysis; D Manuscript Preparation; E - Funds Collection.

Aim of the study to determine cognitive predictors of schoolchildren's hubristic motivation.

Methodology. The complex of methods of psychodiagnostics contained a scale of academic self-control (P.R. Perry, adapted by T. Hordeyeva), 
academic self-efficacy scale (F. Pajares, adapted by T. Hordeyeva), the scale of the diagnosis of implicit theories of abilities (C. Dweck, adapted by T. Hordeyeva), questionnaire to study the attributive style of schoolchildren (T. Hordeyeva, Ye. Osin ma V. Shevyakhova), questionnaire for hubristic motivation. The sample consisted of 431 schoolchildren in grades 7-11, among which 242 with high academic performance and 189 with poor academic performance.

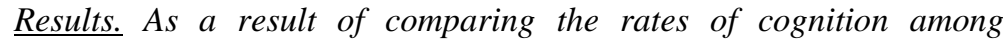
students with different academic successes, it has been determined that academically successful students have higher academic self-control and self-efficacy, optimism in general and optimism in achievement and communication, optimism in success and failure situations, and lower rates of fixed mindset. The correlations between the hubristic aspirations and the academic self-efficacy, growth mindset, self-control attributive style of schoolchildren are determined.

Conclusions. The cognitive factors of hubristic motivation in our study include the system of cognition, represented by ideas about their own effectiveness in activities and the ability to control learning activities, fixed and growth mindsets and attributive style. High academic performance of students positively affects their ability to control learning activities, belief in their own abilities and performance, optimistic attitude to learning and communication, the belief in the globality and the stability of success and the ability to control failures, to solve difficult life situations. Hubristic striving to perfection correlates with academic self-efficacy, achievement optimism, and hubristic striving to superiority correlates with academic self-control, optimism in communication and failure situations. It has been established that the most influential predictors of the development of a hubristic motive for achieving the perfection in schoolchildren is the idea of their own ability to overcome educational difficulties. The cognitive predictors of hubristic motive for achieving the superiority are the idea of the ability to independently control the course of educational activities and independently influence its results. The optimistic attributive style of schoolchildren positively affects both forms of the hubristic motivation of schoolchildren.

Keywords: hubristic motivation, academic self-control, academic selfefficacy, fixed and growth mindsets, attributive style, schoolchildren.

Когнітивні предиктори губристичної мотивації школярів

Карина І. Фоменко

Надія Жукова ${ }^{3}$ Вікторія Надьон 


\section{1,3,4 - Харківський національний педагогічний університет імені Г.С. Сковороди; \\ ${ }^{2}$ - ДУ «Інститут охорони здоров'я дітей та підлітків НАМН України», м. Харків, Украӥна}

Мета дослідження - визначити когнітивні предиктори губристичної мотивачії иколярів.

Методи $i$ вибірка дослідження. Комплекс методів психодіагностики містив шкалу академічного самоконтролю (П. Перрі, адаптований Т. Гордеєвою), шкалу академічної самоефективності (Ф. Паярес, адаптований Т. Гордеєвою), шкала діагностики імпліцитних теорій здібностей (К. Двек, адаптована Т. Гордеєвою), опитувальник для вивчення атрибутивного стилю школярів (Т. Гордеєва, Є. Осін та В. Шевяхова), опитувальник для вивчення губристичної мотивачії. Вибірка складалася з 431 школяра 711 класів, серед яких 242 з високою академічною успішністю і 189 з поганою академічною успішністю.

Результати. В результаті порівняння темпів пізнання серед студентів з різними академічними успіхами було визначено, що академічно успішні студенти мають вищу академічну самоконтроль $i$ самоефективність, оптимізм в иіілому та оптимізм у ситуаціях досягнення та спілкуванні, оптимізм у ситуаціях успіху та невдачі, а також зниження фіксованих когнітивних установок. Визначено кореляційні зв'язки між губристичними прагненнями та академічною самоефективністю, когнітивною установкою на зростання інтелекту, самоконтролю в атрибутивному стилі школярів.

Висновки. Когнітивні предиктори губристичної мотивації в нашому дослідженні включають систему когніцій, представлену уявленнями про їх власну ефективність у діяльності $i$ здатність контролювати навчальну діяльність, імплічитні теорії інтелекту $i$ атрибутивний стиль. Висока академічна успішність учнів позитивно впливає на їхню здатність контролювати навчальну діяльність, віру в власні здібності та продуктивність, оптимістичне ставлення до навчання та спілкування, віру в глобальність і стабільність успіху та здатність контролювати невдачі, вирімувати складні ситуаиіі життя. Губристичне прагнення до досконалості співвідноситься $з$ академічною самоефективністю, оптимізмом у ситуаџіях досягнення, а губристичне прагнення до переваги корелює $з$ академічним самоконтролем, оптимізмом у спілкуванні та ситуаціями невдач. 
Встановлено, щчо найбільш впливовими предикторами розвитку губристичного мотиву досягнення досконалості у школярів є уявлення про власну здатність подолати навчальні труднощі. Когнітивні предиктори губристичного мотиву досягнення переваги є віра $y$ здатності самостійно контролювати прочес навчальної діяльності та самостійно впливати на ї результати. Оптимістичний атрибутивний стиль школярів позитивно впливає на обидві форми губристичної мотивації школярів.

Ключові слова: губристична мотивація, академічний самоконтроль, академічна самоефективність, імпліцитні теоріі інтелекту, атрибутивний стиль, школярі.

Introduction. A lot of foreign and domestic research has been devoted to the study of various cognitive predictors of activity motivation since 1970s. B. Weiner, C. Dweck, M. Seligman, A. Bandura, and E. Skinner offer various options for cognitive constructs designed to explain the mechanisms of motivation functioning in achievement and self-affirmation activities. The subjects' generalized belief that they can cope with this type of activity is an important predictor that influences the nature of their goals in relation to this activity - the goals of superiority or perfection achievement.

Cognitive determinants of motivation traditionally include the system of cognition (ideas, beliefs and mindsets) about the ability of their own intellectual abilities to development, represented by implicit theories of intelligence, the beliefs of their ability to master or perform a certain activity, represented by self-efficiency and beliefs about their own ability control activities (self-control), the attributive-style characteristics of the subject. Consideration of these cognition as a cognitive peculiarities of the emergence of a hubristic motivation is productive, since these variables describe the system of beliefs about their own success, opportunities, probabilities and ways of achieving success.

T. Hordeyeva (2013) indicates that self-efficacy theory, proposed by A. Bandura (1977), was one of the most influential concepts of cognitive predictors of motivation. The attractiveness of the construction of self-efficacy is primarily due to the fact that it is 
one of the most powerful predictors of academic achievement of the subject of educational and training activities.

Self-efficacy is defined as the perception of ability to master or carry out certain activities, to carry out certain behavior at certain level, and also as a belief in ability to regulate the functioning and to control the events that affect live (Bandura, 1986, 1997), it is "the judgment of people about their ability to organize and carry out the actions necessary to achieve the established results of activity" (Bandura, 1986, c. 391). According to this concept, the attractiveness of the result and the belief in the positive result (expectation of success) is not sufficient to trigger the motivation of the subject, which becomes possible only if there is a belief in ability to cope with this type of activity. Self-efficacy is an essential factor both for achievements in various activities, and for physical and psychological well-being (Hordeyeva, 2013). Thus, representations constituting self-efficacy, become the basis for the self-esteem of personality associated with its hubristic motivation.

According to A. Bandura's point of view, self-efficacy is not a function of human skills or abilities, but depends on beliefs and thoughts about the ability to cope with different situations and successfully manifest in them. The theory of self-efficacy predicts that people will (1) strive to avoid situations they believe they can not cope (2) take part in situations and activities that they consider to be able to cope (cited by Hordeyeva, 2013). Thus, self-efficacy is a construct related to the level of personality claims and determines the strategy for success or avoidance of failure, therefore as proved in our previous study (Khomulenko \& Fomenko, 2012), the negative connection of hubristic motivation with the failure avoidance motive implicitly points to positive role of self-efficacy in the hubristic motivation's formation.

Since the criteria of skill and competence are used in measuring self-efficacy, and the psychological content of this construct is the expectation of personal skill in solving future productive tasks (Hordeyeva, 2013), the primary role of self-efficacy in the functioning of hubristic motive for achieving perfection becomes apparent. 
Self-efficacy as a perception of one's own abilities influences the chosen goals and their achievement (Locke, 1990). The perception of the effectiveness determines the type and level of goals: the expressed self-efficacy contributes to the attachment to difficult goals associated with interest in the task itself (Bandura 1986, 1997). Self-efficacy is a factor in academic achievement at school (Gizhinsky, 2016; Gordeeva, Leontiev, Osin, 2011; Schunk, 1981; 2002) and University (Chemers, Li-tze, Garcia, 2001; Robbins, 2004). Students who believe they are able to cope with academic tasks also use more cognitive and metacognitive strategies than those who do not have such belief.

Consequently, the positive impact of self-efficacy on successful activity and the motivation of leading activity, academic performance and overcoming of difficulties and failures has been shown by the researchers as a ground for determining it as an important factor of hubristic motivation.

In addition to beliefs in their own abilities, an important cognitive and motivating factor of activity is beliefs in the possibilities of self-development and personal growth, in particular improving their own mental abilities. C. Dweck (Dweck, 1988) has determined implicit theories of intelligence (two ways of perception of intelligence). People with entity theory or fixed mindset believe that intelligence practically does not change during a lifetime and is a stable structure, the possibility of influence on which a person is insignificant. People convinced that their intellect can be actively developed through their own efforts ("incremental theory" or "growth mindset"), believe that intelligence is plastic and can be successfully trained at any age. In this case, the subjects seek to increase their competence, using complex tasks that are characterized by novelty and variety. The reaction of others is not so important to them. The motivation is dominated by the desire to master new knowledge and skills, competence. "Rage to master" subject chooses difficult tasks, shows perseverance and optimism. "Learned helplessness" subject reduces the quality of the activity after failure, avoids risk, shows a lack of persistence, has "fixed mindset".

The advantage of any of these two orientations depends on the specifics of cognitive self-regulation of activity. "Rage to master" 
subject failures will be associated with unstable internal (for example, lack of effort), or external (bad external conditions) variables. For the "helpless" subjects, failures in activities are due to certain internal stable causes, with which nothing can be done (for example, the lack of abilities) (Hordeyeva, 2008).

The positive role of the optimistic attributive style for the development of hubristic motivation is obvious, as optimists demonstrate greater productivity (Levchenko, 2014). K. Muzdybayev (2003) proves the positive role of optimism in the course of such positive psychological states of personality, such as cheerfulness, a sense of happiness and satisfaction with various aspects of life. It proves that psychological resistance to stress and difficulty of activity, high productivity is due to optimism and is a condition for constructive self-affirmation of a person associated with hubristic motivation.

In modern psychology, two main approaches to optimism have emerged: 1) the interpretation of it as a system of dispositions (Scheier, 1994) and 2) considering it as a style of explanatory style (attributional style or explanatory style) (Seligman, 2015). Both approaches to optimism largely complement each other. They arose in the context of cognitive psychology and, accordingly, link up optimism with the dynamics of processes of the information recycling. According to the dispositional approach, the main are the goals are and the expectations (feeling of confidence / doubts about reaching the goal). Thus, this approach to optimism proceeds from the theory of expected value, according to which there are two conditions for the functioning of the motivation: 1) the attractiveness of the result and 2) the belief in its reachability (McClelland, 2007). Construct of dispositive optimism is connected with the second condition of motivation (belief in a results' reachability). In our opinion, the belief in the attainment of the result that underlies dispositive optimism, along with self-efficacy and the theory of incremental intelligence, forms the cognitive basis for the motivation of the subject of activity, in particular, the hubristic one.

According to the attributive approach (Seligman, 2015), the explanatory style (attributive style) can be characterized by three parameters: 1) consistency or stability (measure of stability 
explaining favorable and unfavorable events over time), 2) latitude or globality (stability explanations for a whole class of situations) and 3 ) personalization, or controllability (explanation of "good" and "bad" events by random, superficial and non-essential reasons, or reasons deeply rooted in one's own personality). In our study conducted with M. Kuznetsova (2016), we have shown a greater degree of interdependence of the hubristic desire to superiority with the parameters of optimistic attributive style.

The concept of optimism, an alternative to a purely cognitive approach, is developed by I. Dzhidzryan (2013) within the emotional-sensual triad "Faith - Hope - Love". Optimism as a positive attitude and perception of the future, is fully expressed in the component of the Belief. It is the Belief in a bright future in an opportunity to improve society, despite the possible obstacles.

Consequently, to the cognitive component of the psychological determination of the motivation of the subject of activity is the system of beliefs - first of all, the belief in their own ability to cope with complex tasks within the activity, the belief in the ability to develop their own mind and ability, as well as the belief in the positive outcome of the future activities and their own role in it. The indicated cognitive features of the subject of activity are included in the characteristic of positive thinking of the individual. According to Zh. Virna (2014), the formation of the phenomenon of a positive person lies through the choice of a particular way of life and activity, through the formation of the behavior on the basis of positive thinking, and also predetermined by specific social conditions. At a relatively equal level of needs in society, each positive personality is characterized by their individual way of their implementation, therefore, the behavior of people is different and depends on many factors. In order to further successful organization of life, to foresee certain events and phenomena, the person should be guided by a positive orientation and an orientation towards the positive result of the life.

The Aim of the study to determine cognitive predictors of schoolchildren's hubristic motivation.

Methodology. The complex of methods of psychodiagnostics contained a scale of academic self-control (P.R. Perry, adapted by 
T. Hordeyeva), academic self-efficacy scale (F. Pajares, adapted by $\mathrm{T}$. Hordeyeva), the scale of the diagnosis of implicit theories of abilities (C. Dweck, adapted by T. Hordeyeva), questionnaire to study the attributive style of schoolchildren (T. Hordeyeva, Ye. Osin та V. Shevyakhova), questionnaire for hubristic motivation. The sample consisted of 431 schoolchildren in grades 7-11, among which 242 with high academic performance and 189 with poor academic performance.

Results. As a result of comparing the rates of cognition among students with different academic successes, it has been determined that academically successful students have higher academic selfcontrol and self-efficacy, optimism in general and optimism in achievement and communication, optimism in success and failure situations, and lower rates of fixed mindset.

Table 1

\section{Indicators of cognitions of schoolchildren's with different academic performance}

\begin{tabular}{|l|l|l|l|l|}
\hline \multirow{2}{*}{ Indicators } & \multicolumn{2}{c|}{$\begin{array}{c}\text { Groups by academic } \\
\text { performance }\end{array}$} & $\mathrm{t}$ & $\mathrm{p}$ \\
\cline { 2 - 3 } & \multicolumn{1}{|c|}{ Successful } & \multicolumn{1}{|c|}{ Unsuccessful } & & \\
\hline $\begin{array}{l}\text { Academic } \\
\text { Self-control }\end{array}$ & $29,30 \pm 4,99$ & $27,65 \pm 5,78$ & 3,18 & 0,002 \\
\hline $\begin{array}{l}\text { Academic } \\
\text { Self- efficacy }\end{array}$ & $13,92 \pm 3,70$ & $12,95 \pm 4,40$ & 2,47 & 0,014 \\
\hline Growth mindset & $17,68 \pm 2,87$ & $17,13 \pm 3,24$ & 1,87 & 0,063 \\
\hline Fixed mindset & $9,27 \pm 3,40$ & $10,88 \pm 4,78$ & $-4,07$ & 0,0001 \\
\hline Optimism & $226,29 \pm 30,23$ & $211,64 \pm 39,60$ & 4,36 & 0,0001 \\
\hline $\begin{array}{l}\text { Optimism in } \\
\text { achievement } \\
\text { situations }\end{array}$ & $164,36 \pm 27,66$ & $154,21 \pm 32,40$ & 3,50 & 0,001 \\
\hline $\begin{array}{l}\text { Optimism in } \\
\text { communicative } \\
\text { situatuins }\end{array}$ & $61,94 \pm 9,79$ & $57,44 \pm 12,15$ & 4,26 & 0,0001 \\
\hline Optimism in failure & $141,68 \pm 17,32$ & $132,58 \pm 23,40$ & 4,64 & 0,0001 \\
\hline Optimism in success & $84,61 \pm 15,32$ & $79,04 \pm 18,10$ & 3,46 & 0,001 \\
\hline
\end{tabular}


Consequently, more successful in learning students are convinced of their own ability to be successful and productive, to control their own learning achievements than less successful students. Students who are more successful in learning are optimists, they are convinced of the stability and globality of success, able to control failures, confident in their own learning and communication success. Less successful in learning schoolchildren are focused on the fact that their own mental abilities can not be improved and developed.

According to the correlation analysis of the indicators of cognition and the student's hubristic motivation, the following tendencies are shown. The positive correlation of indicators of aspiration of superiority with academic self-control indicators $(0,45$, $\mathrm{p}<0.0001)$ was revealed. Consequently, the higher is the desire for superiority over others in schoolchildren, the greater is the level of formation of ideas that successes and failures in the initial activity are controlled by the subject of educational activity. The desire for perfection is more closely related to the notions of controllability $(0,12, \mathrm{p}<0,05)$ and productivity of educational activities $(0,64, \mathrm{p}$ $<0,0001)$. Confident in likelihood of feasible learning objectives students strive for perfection.

Thus, the dominance of the striving for perfection is more closely related to the academic self-efficacy of students, and the domination of desire for superiority is responsible for developing ideas about the ability to control academic achievements.

As a result of the correlation analysis, a positive correlation was found between the desire for perfection with dominance of the growth mindset in the development of intellectual abilities in the system of cognition of schoolchildren $(0,34, \mathrm{p}<0,0001)$. Hence, the focus on improving their own qualities and abilities is inherent in schoolchildren who tend to consider their own intellect as a flexible instrument that is subjected to developmental influence, who are convinced that later their intellect will become more advanced and that there are many opportunities for intellectual self-improvement. Schoolchildren who strive for excellence do not share the view that intelligence is sustainable, and mental abilities can not be improved. 
The correlation between the hubristic aspirations and the attributive style of schoolchildren are determined. Indicators of the hubristic desire for perfection are more related to the optimistic attributive style, in particular with its parameters such as optimism in success $(0,64, p<0,0001)$ and achievements $(0,63, p<0,0001)$ The hubristic desire for superiority also implies a high level of optimism among schoolchildren, but more strongly affects optimism in interpersonal communication $(0.58, \mathrm{p}<0.0001)$. Consequently, the desire for perfection of the subject of educational activity is associated with indicators of optimism, which manifests itself in the field of achievements in educational activity. The belief in the success of learning, due to persistent and internally controlled reasons, is characteristic of pupils who strive for excellence and superiority.

Optimism in interpersonal communication, which is characteristic of pupils with a high hubristic desire for superiority, is characterized by beliefs in the ability to control the effects of interpersonal communication, to consider their qualities, abilities and actions as a reason for success in communicating with others. In addition, the desire for superiority implies a high level of development of optimism in situations of failure. So, schoolchildren who are eager to win in situations of failure are convinced that next time they will be more lucky, especially if they make efforts and take into account previous mistakes and shortcomings.

According to the results of multiple regression analysis, cognitive predictors of the hubristic motivation of the subject of educational activity were identified (tables 2 and 3). The most influential cognitive predictor of the pursuit of perfection is academic self-efficacy as an idea of its own ability to perform the most complex tasks, to cope with the difficulties of learning activities $(\beta=0,48 ; \mathrm{t}=11,88 ; \mathrm{p}<0,00001)$.

Table 2

Results of multiple regression analysis of cognitive predictors of desire for perfection of schoolchildren

\begin{tabular}{|c|c|c|c|c|c|}
\hline \multicolumn{1}{|c|}{ Predictors } & $\beta$-value & $\begin{array}{c}\text { Standaart } \\
\text { emor }\end{array}$ & $\begin{array}{c}\mathrm{F}- \\
\text { value }\end{array}$ & $\mathrm{T}$ & $\mathrm{p}$ \\
\hline Intercept & & & 9,4989 & 4,189 & 0,0000 \\
\hline
\end{tabular}


Вісник ХНПУ імені Г.С. Сковороди. Психологія. Випуск 60

\begin{tabular}{|c|c|c|c|c|c|}
\hline $\begin{array}{l}\text { Academic } \\
\text { Self-control }\end{array}$ & 0,1371 & 0,0377 & $-\overline{0,1695}$ & 3,637 & 0,0003 \\
\hline $\begin{array}{l}\text { Academic } \\
\text { Self- efficacy }\end{array}$ & 0,4767 & 0,0401 & 0,7877 & 11,880 & 0,0000 \\
\hline Growth mindset & 0,1498 & 0,0359 & 0,3290 & 4,175 & 0,0000 \\
\hline Fixedmindset & $-0,1008$ & 0,0365 & 0,1630 & $-2,762$ & 0,0060 \\
\hline Optimism & 0,3501 & 0,0429 & 0,0662 & 8,157 & 0,0000 \\
\hline
\end{tabular}

The optimism $(\beta=0,35 ; \mathrm{t}=8,15 ; \mathrm{p}<0,00001)$ as an attributive style of explaining successes as stable, controlled and comprehensive in life, and failures - as specific and internally controlled. Positive is also the growth mindset as a characteristic of the theory of incremental intelligence of the subject of educational activity in the primary school, through which the student evaluates his own mental abilities as those that can be developed and improved. In addition, there is a positive effect of academic self-control of the student on the hubristic pursuit of perfection $(\beta=0,14 ; \mathrm{t}=3,6 ; \mathrm{p}<0,001)$. Fixed mindset has a negative contribution to the hubristic pursuit of perfection $(\beta=-0,10 ; \mathrm{t}=-2.8 ; \mathrm{p}<0,01)$.

The contribution of cognitive predictors in the development of the desire to benefit students is established (Table 2). The most significant is the positive role of academic self-control $(\beta=0,38 ; \mathrm{t}=$ $7,99 ; \mathrm{p}<0,00001)$. Consequently, the idea of their own ability to control the results and consequences of learning activities, awareness of their own leading role in the success of educational activities are favorable for the formation of the desire for superiority.

Table 3

Results of multiple regression analysis of cognitive predictors of desire for superiority of schoolchildren

\begin{tabular}{|l|l|l|l|l|c|}
\hline \multicolumn{1}{|c|}{ Predictors } & $\beta$-value & $\begin{array}{c}\text { Standaart } \\
\text { emor }\end{array}$ & $\begin{array}{c}\text { F- } \\
\text { value }\end{array}$ & $\mathrm{T}$ & $\mathrm{p}$ \\
\hline Intercept & & & 10,965 & 4,000 & 0,0001 \\
\hline $\begin{array}{l}\text { Academic } \\
\text { Self-control }\end{array}$ & 0,3845 & 0,0481 & 0,451 & 7,996 & 0,0000 \\
\hline $\begin{array}{l}\text { Academic } \\
\text { Self- efficacy }\end{array}$ & $-0,1593$ & 0,0512 & $-0,250$ & $-3,112$ & 0,0020 \\
\hline Growth mindset & $-0,0288$ & 0,0458 & $-0,060$ & $-0,630$ & 0,5288 \\
\hline
\end{tabular}




\begin{tabular}{|l|l|l|l|l|l|}
\hline Fixed mindset & $-0,0939$ & 0,0466 & $-0,144$ & $-2,017$ & 0,0443 \\
\hline Optimism & 0,2019 & 0,0547 & 0,036 & 3,688 & 0,0003 \\
\hline
\end{tabular}

Optimism as the characteristics of globalization, stability and controllability of the consequences of its own activities in the areas of communication and learning in schoolchildren is a significant predictor of the desire to superiority $(\beta=0,20 ; \mathrm{t}=3,7 ; \mathrm{p}<0,001)$. The notion of their own abilities, both unstable and non-developing, has a negative impact on the development of the desire to superiority.

Consequently, among the cognitive predictors of the hubristic motivation of the subject of educational activity in the main school, the most significant are optimism, implicit theories of "augmented" intelligence, as well as academic self-efficacy, which predetermines the development of the pursuit of perfection, and academic selfcontrol, which has a positive effect on the aspirations to superiority.

Regression equations have been defined for indicators of the hubristic pursuit of perfection and superiority:

Hubristic striving for perfection $=9,49+0,13$ Academic Selfcontrol $+0,47$ Academic Self- efficacy $+0,15$ Growth mindset 0,10 Fixed mindset + 0,35 Optimism.

Hubristic striving for superiority $=10,96+0,38$ Academic Self-control - 0,16 Academic Self- efficacy - 0,09 Fixed mindset + 0,20 Optimism.

Consequently, the most influential cognitive factors in the development of the hubristic motivation of schoolchildren is the belief of their own ability to overcome learning difficulties, which determines the hubristic desire for perfecion, and the belief of the ability to independently control the course of learning and independently influence on its results, which positively influences the development of the desire for superiority. The optimistic attributive style of schoolchildren positively affects both forms of the hubristic motivation.

Discussion. Hubristic motivation of the subject of educational activity is associated with an optimistic attributive style. Such data correlates with the proved T.O. Hordeyeva (2009) thesis on the 
benefits of optimism in overcoming the fear of failure and the formation of the desire to overcome difficulties and achieve high results in learning activities, as the motivation for success positively correlates with the student's hubristic aspirations.

T. Hordeyeva (2013) proves the connection between the implicit theory of incremental intelligence, academic self-efficacy and selfcontrol with motivation for achievement among schoolchildren, and in our previous study (Khomulenko \& Fomenko, 2012) a high correlation between hubristic motivation and achievement motivation is shown, therefore, entirely it is obvious that the idea of their own productivity and the ability to control the educational activity, as well as to develop their intellect, are positively associated with hubristic motives.

Conclusions. The cognitive factors of hubristic motivation in our study include the system of cognition, represented by ideas about their own effectiveness in activities and the ability to control learning activities, fixed and growth mindsets and attributive style.

High academic performance of students positively affects their ability to control learning activities, belief in their own abilities and performance, optimistic attitude to learning and communication, the belief in the globality and the stability of success and the ability to control failures, to solve difficult life situations.

Hubristic striving to perfection correlates with academic selfefficacy, achievement optimism, and hubristic striving to superiority correlates with academic self-control, optimism in communication and failure situations.

It has been established that the most influential predictors of the development of a hubristic motive for achieving the perfection in schoolchildren is the idea of their own ability to overcome educational difficulties. The cognitive predictors of hubristic motive for achieving the superiority are the idea of the ability to independently control the course of educational activities and independently influence its results. The optimistic attributive style of schoolchildren positively affects both forms of the hubristic motivation of schoolchildren.

\section{References}

Bandura, A. (1997). Self-efficacy. The exercise of control. New York: Freeman and Co.

Bandura, A. (1977). Self-efficacy: Toward a unifying theory of behavior change. Psychological Review, 84, 191-215. 
Bandura, A. (1986). The social foundations of thought and action: A social cognitive theory. Englewood Cliffs (NJ): Prentice Hall.

Chemers, M.M., Li-tze, H. \& Garcia, B.F. (2001). Academic selfefficacy and first-year college student performance and adjustment. Journal of Educational psychology, 93, 1, 55-64.

Dweck, C.S.\& Leggett, E.L. (1988). A Social-Cognitive Approach to Motivation and Personality. Psychological Review, 95, 2, 256-273.

Locke, E.A. \& Latham, G.P. (1990). A theory of goal setting and task performance. Englewood Cliffs (NJ): Prentice-Hall.

Norem, J. K. \& Cantor, N. (1986). Defensive pessimism: Harnessing anxiety as motivation. Journal of Personality and Social Psychology. 51. 1208-1217.

Pietsch, J., Walker, R. \& Chapman, E. (2003). The relationship among self-concept, self-efficacy and performance in Mathematics during secondary school. Journal of Educational Psychology. 95(3), 589-603.

Robbins, S.B., Lauver, K., Le H., Davis, D. \& Langley R. (2004). Do psychosocial and study skill factors predict college outcomes? Psychological Bulletin, 130. 261-288.

Scheier, M.F., Carver, C.S. \& Bridges, M.W. (1994). Distinguishing optimism from neuroticism (and trait anxiety, selfmastery, and self-esteem): A reevaluation of the Life Orientation Test. Journal of Personality and Social Psychology, 67. 1063-1078.

Schunk, D.H. (1981). Modeling and attributional feedback effects on children's achievement: A self-efficacy analysis. Journal of Educational Psychology, 74, 93-105.

Schunk, D.H. \& Miller, S.D. (2002). Self-efficacy and adolescents' motivation. In F. Pajares \& T. Urdan (Eds.), Academic motivation of adolescents. Greenwich, CT: Information Age, 29-52.

Virna, Zh.P. (2014). Orhanizatsiya zhyttya pozytyvnoyi osobystosti: konstruktyvna prohnostyka ta profesiyna uspishnist' [Organization of the life of a positive person: constructive prognosis and professional success] Nauka i osvita-Science and Education. 9, 65-71.

Gizhinsky, V.V. (2016). Vnutrenniye i vneshniye motivy uchebnoy deyatel'nosti kak faktory akademicheskoy uspeshnosti starsheklassnikov [Internal and external motives of educational activity as factors of academic success of high school students:] (Doctoral dissertation). [in Russian].

Hordeyeva, T.O., Leontyev, D.A., Osin, E.N. (2011). Vklad lichnostnogo potentsiala $\mathrm{v}$ akademicheskiye dostizheniya [The contribution of personal potential to academic achievement] Lichnostnyy potentsial: 
struktura i díagnostika - Personal potential: structure and diagnostics. Moskva: Smysl. [in Russian].

Hordeyeva, T.O., Osin, E.N., Shevyakhova, V.Yu. (2009). Diagnostika optimizma kak stilya ob"yasneniya uspekhov i neudach: oprosnik STOUN. [Diagnostics of optimism as a style of explaining successes and failures: STOUN questionnaire]. Moskva: Smysl. [in Russian].

Hordeyeva, T.O. (2013). Motivatsiya uchebnoy deyatel'nosti shkol'nikov i studentov: struktura, mekhanizmy, usloviya razvitiya [Motivation of educational activity of schoolchildren and students: structure, mechanisms, conditions of development] (Doctoral dissertation). [in Russian].

Hordeyeva, T.O. (2006). Psikhologiya motivatsii dostizheniya [Psychology of achievement motivation]. Moskva: Smysl. [in Russian].

Dzhidaryan, I.A. (2013). Psikhologiya schast'ya $i$ optimizma Psychology of happiness and optimism. Moskva: Institut Psichologii, RAN.

Kuznetsov, O.I. \& Fomenko, K.I. (2015). Motyvatsiyni faktory psykhichnykh staniv studentiv u riznykh umovakh navchal'noyi diyal'nosti [Motivational factors of mental states of students in different learning environment]. Visnyk KHNPU imeni H.S. Skovorody. Psykholohiya Herald of H.S. Skovoroda KhNPU. Psychology. 50. Kharkiv: KhNPU, 278292.

Levchenko, V.V. (2014). Pozitivnaya psikhologiya - Positive psychology. Moskva: FLINTA.

McClelland, D. (2007). Motivatsiya cheloveka - Motivation of the person. Sankt-Peterburg: Piter.

Muzdybaev, K. (2003). Optimizm i pessimizm lichnosti [Optimism and pessimism of the personality]. Sotsiologicheskiye issledovaniya Sociological studies, 12, 87-96.

Seligman, M. (2015). Kak nauchit'sya optimizmu: Izmenite vzglyad na mir i svoyu zhizn [How to learn optimism: Change the view of the world and your life]. Moskva: Alpina Publisher. [in Russian].

Fomenko, K.I. \& Kuznetsova, M.M. (2016). Hubrystychna motyvatsiya optymistiv ta pesymistiv [Hubristic motivation of optimists and pessimists]. Visnyk KHNPU imeni H.S. Skovorody. Psykholohiya - Herald of the H.S. Skovoroda KhNPU, Psychology, 53, 256-264. [in Ukrainian].

Khomulenko, T.B. \& Fomenko, K.I. (2012). Hubrystychna motyvatsiya yak chynnyk prahnennya do uspikhu: vikovyy aspekt [Hubristic motivation as a factor in the pursuit of success: the age aspect] Kharkiv: KhNPU. [in Ukrainian].

Original manuscript received January, 23, 2019

Revised manuscript accepted February, 5, 2019 